\title{
TWEE HISTORISCHE LIEDEREN IN SURINAME
}

\author{
DOOR
}

THEOD. A. C. COMVALIUS

$\mathrm{Bij}$ de bestudeering van het oud-Surinaamsche lied werd onze aandacht getrokken door twee liederen, die op het einde der $18 \mathrm{e}$ eeuw zijn ontstaan: het eene kort na de benoeming van Jurriaan François de Friderici tot Gouverneur van Suriname (1790-1802) en het andere bij de overname van de kolonie door Engeland (1799-1802).

A. Men herinnert zich wellicht, dat, toen in 1799 het Engelsch Bestuur was ingetreden, Friderici als Gouverneur werd gehandhaafd, hetgeen hem bij de teruggave van Suriname in 1802 aan Nederland heel wat onaangenaamheden heeft berokkend.

Friderici is de eenige Gouverneur van Suriname geweest, die in zeer nauw contact met de bevolking heeft gestaan. Niet alleen omdat hij zijn loopbaan als officier was begonnen, waardoor hij zich vrijer mocht bewegen en zich beter op de hoogte van de toen bestaande toestanden kon stellen, maar vooral omdat hij gedurende de oorlogen tegen de Marrons met zijn zwarte soldaten de bosschen in allerlei richtingen had te doorkruisen en op deze tochten lief en leed met zijn corps moest deelen.

Zijn soldaten bestonden voor het meerendeel uit Afrikanen, die als gouvernements-slaven ${ }^{1}$ ) waren aangevoerd en werden aangeduid met den naam: Guiden.

Door persoonlijke aanraking wist hij hun moed te waardeeren. Vandaar dat hij na zijne benoeming tot Gouverneur erop bedacht was, om den dapperen een duurzaam blijk van die waardeering te geven. Hij liet in de omstreken van Paramaribo

1) De gouvernementsslaven werden van de overige afgezonderd op een terrein ten Westen van Paramaribo, toen bekend als 's Lands Grond, en stonden onder bescherming van een ambtenaar, die tevens beheerder was van dat stadsdeel, de vaarten, bruggen en markten. Een dezer functionarissen was de stichter van ons geslacht in Suriname, Johannes Comvalius. 
aan zijne oud-strijders perceelen in eigendom afstaan, waar zij zich konden vestigen, kostgronden aanleggen en een rustigen ouden dag tegemoet gaan.

Het spreekt wel vanzelf, dat de begiftigden voor deze gunst zeer gevoelig waren. En wanneer de oogst werd binnengehaald, lieten zij een loflied hooren, dat niet van eenige overdrijving is vrij te pleiten, gelijk uit de woorden blijkt.
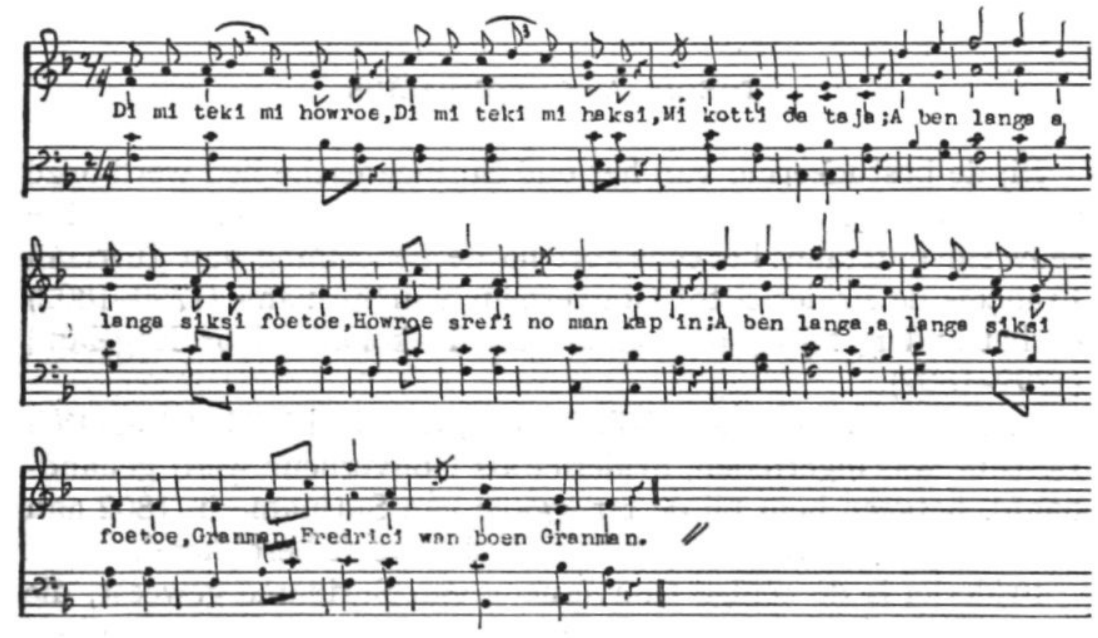

Vertaald zegt ons dit lied toch niets minder, dan dat de bodem der perceelen zóó vruchtbaar was (zeker omdat de grond hun door Friderici geschonken was), dat de aardvruchten, tajers e.a., die er uitgehaald werden, wel zes voet lang waren en slechts met een bijl konden worden aan stukken gemaakt.

Maar deze lieden waren soldaten geweest en niet vreemd aan het gebruik van de hyperbole.

B. Het andere lied, dat een kinderspel begeleidt, bezingt den inval der Engelschen in Suriname in het jaar 1799. Bij dit spelletje zit een aantal kinderen in een grooten kring met uitgestrekte beenen. Terwijl er gezongen wordt, treedt een ander kind, meestal het jongste onder de aanwezigen, in den kring en begint op de maat van het liedje de beentjes één voor één zacht aan te raken. De persoon, wiens been bij de laatste maat van het liedje wordt aangeraakt, moet dat been terugtrekken. Deze handeling herhaalt zich, totdat er slechts één been is uitgestrekt. Dit kind is dan ,"blijven zitten” en verbeurt een pand. Maar meestal wordt het gevraagd, wat het 't liefst zou wenschen: 
koffie of tom-tom. Kiest het tom-tom, dan wordt zijn hiel door den dreumes eenige malen tegen den grond geslagen, om het stampen van de bananen tot tom-tom na te bootsen. Heeft het liever koffie, dan laat de kleine zijn hiel de draaiende beweging maken als bij het malen van koffieboonen.
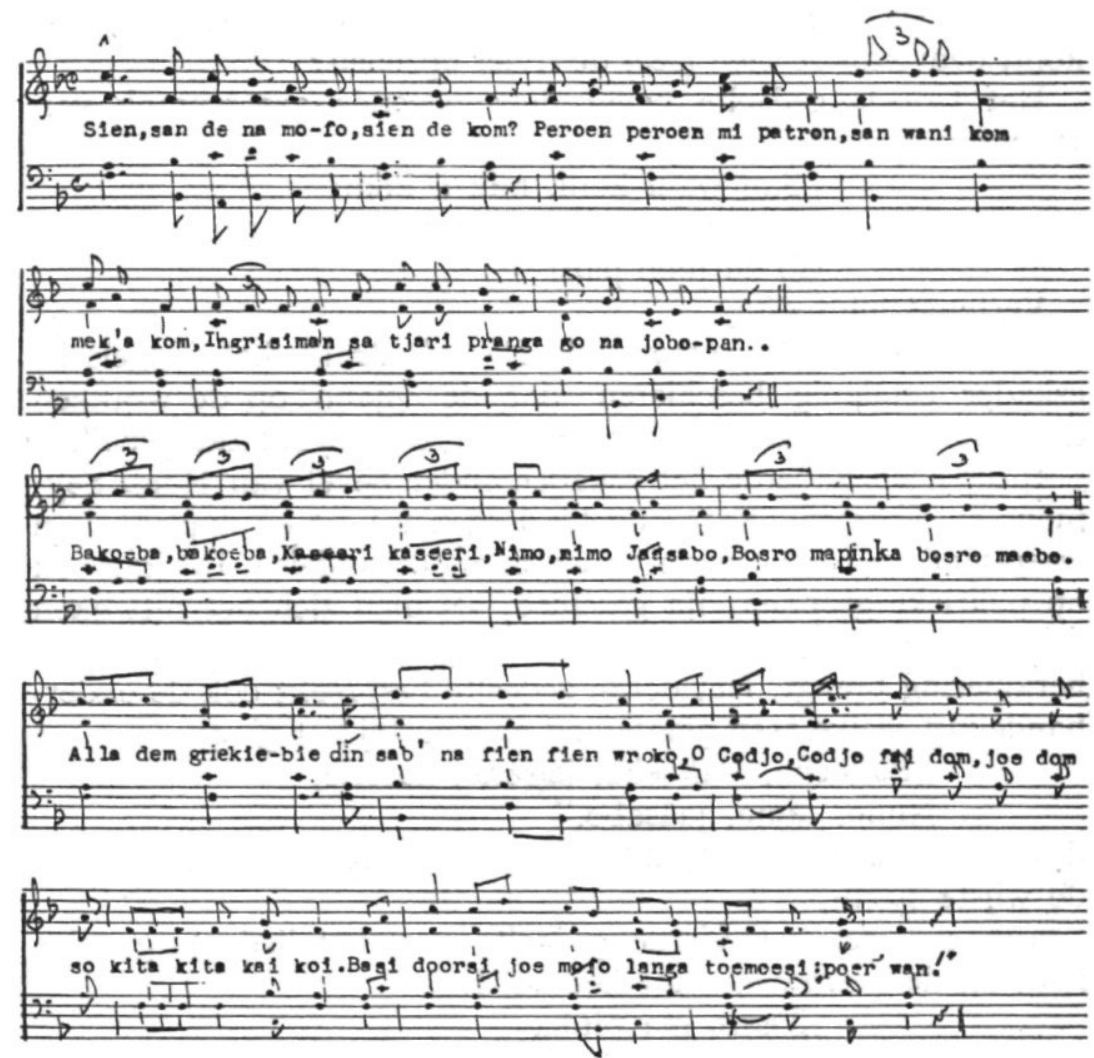

$\mathrm{Nu}$ volgt een verklaring van den inhoud van dit lied. Het bevat in de eerste plaats een vraag:

„Sien, san dee na mofo sien dee kom,

Peroen, Peroen, mi patron?"

Oudtijds bestond aan de samenvloeiing van de Suriname -en de Commewijne-rivieren het fort Nieuw-Amsterdam met eene militaire bezetting, die ten doel had het binnenvaren van vijandelijke oorlogsschepen tegen te gaan. De bezetting bestond uit Guiden en Europeesche soldaten. Op een morgen in het jaar 1799 zag een Guide, die op den uitkijk stond, eenige Engelsche oorlogsschepen de rivier binnenzeilen. Hij maakte alarm. Toen begon- 
nen de overige Guiden dit bericht aan elkaar door te geven, nadat den commandant van het fort, zekeren Peronne, hiervan kennis was gegeven. Sien-Sibie. Alle Negers, die indertijd met hetzelfde schip waren aangevoerd, tot dezelfde plantage behoorden of samen denzelfden werkkring hadden, noemden elkander Sien of Sibie. De vraag is dus: Sibie en commandant Peronne, wat komt daar van de Sien (zee) de rivier opzeilen?

Het tweede gedeelte bevat de snoevende grootspraak van Peronne:

Vertaald luidt dit:

„San wani kom, mik a kom:

Ingrisiman sa tjari pranga

Go na jobo pan!"

Laat komen, wat komen wil. Ik zal straks het Engelsche eskader zoodanig beschieten, dat de vijand op de wrakken ervan naar Jobo pan (het groote water, de zee) zal afdrijven".

Intusschen naderde het eskader onder bevel van Hugh Seymour en Thomas Trigge ongehinderd het Fort en in plaats van weerstand te bieden besloot men te onderhandelen. Dit kan ook op politieke gronden zijn geschied, als men zich het uitwijken van Willem V naar Engeland en hetgeen ermee samenging in herinnering brengt. Het derde gedeelte bespreekt ook de onderhandeling, welke toen plaats had en waarbij het ging:

„Bakoeba, Bakoeba, kaserie, kaserie,

Nimo, nimo, jaâsabo."

d.w.z. men bakte van onzen kant zoete broodjes en koos eindelijk de wijste partij,

wat evenwel het vierde gedeelte van het lied ten gevolge had, nl. de overgave, want het werd:

$$
\begin{aligned}
& \text { "Bosro ma pinka } \\
& \text { Bosro ma bo!" }
\end{aligned}
$$

Men zat in den klem en kon niet anders.

Het vijfde gedeelte bevat de bespotting van den snoevenden commandant:

„Ala dem grikiebie din sab'na fien fien wroko, O Codjo, Codjo, fai dom, joe dom so kita, kita, kai koi!"

Dit beteekent:

Zelfs de kleinste vogels, waaronder de grikiebie, weten zich te redden uit de macht van den jager, omdat zij hun werk (het 
vliegen) goed verstaan en ervoor geschikt zijn. (Dit, om te doen uitkomen, dat Peronne geen goed krijgsman was maar een lafaard). Maar, O Codjo, wat zijt ge dom! Gij zijt niet waard een krijgsman te heeten. Hierbij is de naam van den commandant vervangen door een negernaam, Codjo. Deze naam draagt iemand, die op Maandag geboren is en in den regel voor zeer dom doorgaat.

Hier is het eigenlijke lied geëindigd. Toch is er een aanhangsel als slot bijgevoegd terwille van het spel der kinderen. Want, terwijl ze aan het spelen en zingen zijn, staat een oude neger, baas Dorus, aandachtig alles waar te nemen en de guitjes zingen hem als slot toe:

„Basie Doorsie, Jo mofo langa toemoesie!"

„Baas Dorus, wat heb je een langen mond!"

Let nu ten slotte op het woord toemoesie (teveel).

Terwijl dit woord gezongen wordt, valt de hand van het kind in den kring juist op het been van een der anderen, die volgens den regel van het spel, dat been moet terugtrekken. Het zingt hem dus toe: Poeroe wan!" Dat beteekent: „Trek je been terug!" 